\title{
Connecting Identity and Image of City Branding in Kota Tua (Old City) Jakarta
}

\author{
Rakhmat HIDAYAT, Rina ISMARIATI And Yuanita APRILIANDINI
}

Department of Sociology, State University of Jakarta

Correspondence should be addressed to: Rakhmat HIDAYAT; hidayat@unj.ac.id

Received date: 25 March 2019; Accepted date:11 July 2019; Published date: 10 September 2019

Academic Editor: Vincent Oh

Copyright (C) 2019. Rakhmat HIDAYAT, Rina ISMARIATI And Yuanita APRILIANDINI. Distributed under Creative Commons CC-BY 4.0

\begin{abstract}
The Old City which is called Kota Tua is a historical tourism place in Jakarta which was built by Dutch colonialism in the $17^{\text {th }}$ century. At that time, this location was the center of a Dutch company for spice trade also provided the original town hall as a public sphere for the colonialist. After the independence era, the most famous buildings in this area were Jakarta History Museum and a town hall which is considered a landmark and an icon for this location. The purpose of this paper is to explain the construction of the city branding in the urban landscapes. At this point, this paper draws the attention to the connection of both the identity and the image of the city beyond city branding. On the other side, this paper also focuses on the impact of city branding on the tourism aspect in Jakarta. This study used a qualitative method with a case study research design conducted in Kota Tua. Kota Tua is one of the tourism objects that is still maintaining the historical-cultural-social identity of Jakarta. Kota Tua is one of the icons of the city of Jakarta. As the icon, Kota Tua becomes the model of the city branding project. The subjects in this study were the parties involved in branding Kota Tua Jakarta. The subjects were purposively selected and divided into three categories as follows: key informants, additional informants and triangulation informants. Based on the findings of this study, it is argued that city branding is a potential tool to bring new perspectives as well as new creations which particularly help a site promote the identity and image of the city. In practice, city branding is a part related with the cultural identity of the Kota Tua, which represents colonialism history during the Ducth colonialism. In addition, it was potentially strategic for imagining the urban landscapes. In this case, city branding can be a strategy to connect the historical and cultural heritages with tourism attraction in an advance urban changing. Moreover, this paper covers how city branding contributes to urban landscape which is an urban project for the alternative development in the city.
\end{abstract}

Keywords: City Branding, Tourism, Image, Identity

Cite this Article as: Rakhmat HIDAYAT, Rina ISMARIATI And Yuanita APRILIANDINI (2019)," Connecting Identity and Image of City Branding in Kota Tua (Old City) Jakarta", IBIMA Business Review, Vol. 2019 (2019), Article ID 217784, DOI: 10.5171/2019.217784 


\section{Introduction}

As a product of globalization, cities in the world are currently competing globally to attract capital, manufacturing, talent, technology, tourists, events and wealthy citizens by applying city branding practices. Moreover, this practice is also used to empower the urban development, regeneration and quality of life and is utilized as an attraction in city competition at the global level. Therefore, the city needs brand image as a supporter of competitive and sustainable city developments to compete with other cities (Yananda et al., 2014: 3). As a product produced by a producer, the city needs an image to make the city's reputation different and create an interest in the outside community (consumers) to come and invest. City branding can make a city "sell" what it has in terms of tourism, industry, housing, or economic centers (Yananda et al., 2014: 2). This practice is the most holistic approach to achieve competitiveness. If it is implemented effectively, it can lead to increase the number of customers and investment in the city. Kota Tua Jakarta is one of the cities which is carrying out branding practices by integrating the historical context of the city as an effort to form a positive image for the city. It becomes a narrative of the history of Kota Tua Jakarta along with the values growing from the existing community. Therefore, it gives the city a meaning of identity in the future (Margana \& Nursam, 2010: 35).

Definitely, it is not an easy matter as the development era has slowly uprooted the roots of Kota Tua from its original roots. The examples are the function of various historical heritage buildings that has begun to be replaced, street vendors making the area of Kota Tua, Jakarta looking slum, the existence of modern buildings that surround the area of Kota Tua Jakarta, the emergence of the marginalization of the role of local communities and various other problems. Nevertheless, Kota Tua Jakarta continues to strive to improve conditions and create a positive brand for the desired achievements. The purpose of branding itself is not merely to create something new but also to find what is existing to achieve a goal. A place is distinctive and different from other places. The purpose of a brand is to be an attribute distinguishing one place from another, to place a unique value and convert a place to its destination. The purpose of this study is to describe the application of city branding as a tool to create the desired identity and image for the city, especially Kota Tua Jakarta. The topic of city branding was analysed with many various perspectives. It was built to develop this field of research from many scholars. City branding was developed by a marketing perspective (Hereźniak, Florek, Augustyn, 2018; Purwanto \& Soliha, 2017), and a tourism perspective (Soltani, Pieters, Young and Sun, 2018; Fernández \& Meethan, 2013). On the other side, it was analysed by geography understanding (Kavaratzis \& Kalandides, 2015; Andersson, 2015), urban governance perspective (Ye\&Björner, 2018), semiotic theory (Mueller \& Schade,2012), historical perspective (Briciu \& Briciu, 2016), public diplomacy (Donner, Horlings, Fort, and Vellema, 2016), and cultural perspective (Dinardi, 2017;Bıçakçı, 2012). However, the terms identity and city image of city branding are still not deeply explored yet. Furthermore, this paper will concern to identity as well as city image in the city branding. As Nas, de Groot and Schut (2011) stated, Kota Tua Jakarta can be described as an urban symbolism. It expresses itself through different phenomena, such as the layout of a city, architecture, statues, street and place names, poems, as well as rituals, festivals and processions. On the other side, this paper is similar to the discourse image and symbolic representation of the city (Borer, 2006). In addition, this study was also intended to analyze the city branding of Kota Tua Jakarta in a sociological perspective. In this field, Roubal (2017) called it "sociology branding".

\section{Research Methodology}

This study explores the concept of urban branding from a theoretical, analytical, and practical perspective. The researcher used 
a qualitative approach by employing a case study research design. This type of research is considered to be relevant to use because it describes the state of the object that qualitatively exists in the present based on the data obtained. Qualitative research with a case study is intended to get a clear and a factual description and explanation of the City Branding of Kota Tua Jakarta. The subjects in this study were the parties involved in branding Kota Tua Jakarta. The subjects were purposively selected and divided into three categories, namely; key informants, additional informants and triangulation informants. The subjects were selected to dig information regarding the application and impacts of branding in Kota Tua Jakarta.

\section{Theoretical Framework}

\section{Definition of City Branding}

City Branding comes from urban marketing studies adopted by the commercial world to achieve its goals. City branding deals with building a collective imagination of a city. As a consequence, massive effort is needed and should be consistent with measurable and clear planning for the parameters specified. In implementing city branding, there must be a serious support from the government to get the goals and achievements of a brand that has been built. In developing the brand of city, government, stakeholders, and the community must work together to conduct branding activities so that the image building is not only in the physical aspect but also in the character and other more important potentials possessed by the city itself (Makassar City Government, Vier Antares Institute, 2014: 7). At the theoretical level, the concept of branding is usually developed in response to changes in the status and role of tourism in the global environment. At present, this concept is the subject of much research and analysis from academics and policy makers. City branding itself is an important contemporary problem and continues to be a competition for developing cities. It could help the development of the desired place for a business location, tourism objects or place of residence (Kavaratzis \& Ashworth,
2005: 506). In brief, it explains that city branding is used as a tool to introduce historical, psychological, aesthetic, pragmatic, and cultural considerations of a city (Donald \& Gammack, 2007: 45).

\section{Concept of Identity and Image Building of the City}

According to Kyung and Kim (2011:197), identity is a construction, a consequence of a process of interaction between humans, institutions and practices in social life. In applying city branding, a city tries to build its identity. This city branding activity requires every city to compete in creating a certain image in the minds of the wider community in representing the character of the city. The image of the city has the power to shape the brand of a city. Morover, it might affect the city itself. The brand attached to the city depends on the identity of the city. This is the process of shaping a brand from a city to ease the city owners to introduce and prmote their city to target markets such as investors, tourist, talent, events (Donald \& Gammack, 2007: 14). Meanwhile, brand image is a term that is often blended with brand identity. However, there are differences between the two. Brand identity is the identity of the city and it comes from various city sources; while, the brand image is the image perceived by the recipient or consumer and it comes from consumers. Brand image is a range of multifunctional and intangible features that enable consumers to identify products and services. The point is that the brand image together with consumers involve the attitudes and values of either the company or the customers that cannot be separated from communication. Brand image can be defined as how the consumers identify products or as a number of their understanding of the product. Brand image is the result of consumer representation obtained from various sources about the brand. This is seen as the number of emotional and aesthetic impressions of the product that occur to consumers (Trott \& Sople 2016: 81). 


\section{The Concept of City Branding Strategy}

Strategy is defined as knowing what and where a place is in the perceptions of internal and external stakeholders. Strategy also means knowing where the place will be taken and how to achieve that goal. Substance is the execution of the chosen strategy in the form of new activities in the economic, legal, political, social and cultural fields. Innovation, structure, legislation, reform, investment, institutions, and policies that are truly carried out will bring the place closer to the desired goal (Yananda et al., 2014: 71). Promotion of city identity is considered as a core strategy. This strategy emphasizes the uniqueness of the city by communicating the image of a city that is different from the others to create a place with the desired image. Cities throughout the world are eager to create new identities in order to compete in the increasing global markets. City marketing is a practice that is deliberately created to attract visitors. However, unfortunately, in the practice of city marketing, the original identity of the city is often ignored, rejected, or marginalized. In fact, there are still many ways to achieve the marketing potential that is more integrated and holistic. In this case, city branding has been proposed as a complementary tool and can overcome the shortcomings associated with the traditional city marketing (Lee, 2009: 208). Branding for a city is extremely important because if it hits or is synonymous with the spirit of the city community, it will certainly provide positive vibes for the community. Branding usually becomes a reference for the spirit to form a better community life. However, the branding that smells of Tempoe Doeloe (old) romance becomes bland when various cases emerge with the branding of a city. The polemic about the destruction of various heritage cities, as well as other problems, is finally awakened to how a pile of branding a city is merely a slogan. It seems that the substance of the city has undergone a change in value that drives the pattern of change in identity of its citizens (Lee, 2009: 35).

\section{Findings and Discussion}

\section{City Branding in Urban Landscape}

The practice of city branding is understood as a good means to achieve competitive advantage of the city. It is done to increase investment in the community, achieve community development, and strengthen local identity and identify residents with surrounding cities. At the same time, we must explain city branding, which Forbes (2019:44) defined as "in a market economy, as for example, is manifest in plans and policies to improve competitiveness through expanding the market economy and leveraging global markets." In addition, according to Cabannes, Douglass, and Padawangi (2018:28), city branding can be understood as an urban project which reflects the city as both an idea and a reality that address the people's role in the place making practices. It means that this project must involve citizens from any group because at the same time, city branding constructed a meaningful urban life at the city based on historical-cultural and social contexts of the city. In the process, city branding requires the active role of the city government, stakeholders and local communities as bearers of entities from the city. In addition, the city must also be able to build a local community within it such as how to change the paradigm of awareness of local people as city dwellers and how to make the community play an active role in the construction of the city. It is important because a city needs to package the area approproately so that it can attract more attention.

The current trend is that every region and city compete each other to highlight their identity and package their potential in such a way so that the city can be different from competitors. This is also in line with the goals of branding applied by cities in the world, including in Kota Tua Jakarta. Therefore, the parties involved must be able to go hand in hand to achieve the goals. Moreover, the city must also be able to build its local community so that the city can truly achieve the positive impact of the 
development. For a moment, we also have to feel the sociological imagination in a city where we have to reread the needs of the community, face, and body of the city as a home that they inhabit to live, work and actualize their work,so that we can find out what aspects the city needs in its development process.

\section{Promote Tourism}

The most important thing in city branding is how it contributes to tourism aspect as well as city development. We must see how the city was built and for the benefit of who the city was built. In the branding process of Kota Tua Jakarta, the Provincial Government has collaborated with the private sector to revitalize the city's historic buildings, improve the city's image, and highlight the cultural aspects of Kota Tua Jakarta. The cultural aspects are intentionally used to design Kota Tua Jakarta as attractive as possible to attract visitors or the wider community to come. In addition, various events and festivals are presented to grab visitors' attention. The festivals and events are used as a sign that the city is showing its identity. The events and festivals held were presented to show the local identity of Kota Tua Jakarta such as the historical process during the Dutch colonialism (Matthewson, 2018:192). Kota Tua which still provides history museum and an urban square (alun-alun) represents which Widodo (2019:396) stated as "colonial town" as well as a hegemoni ambitions from the Dutch colonial with the European architectural morphology such as public buildings, urban square and plazas, etc. Moreover, city branding Kota Tua became a socioeducation sphere to promote cultural historial learning for the citizens particularly children, young generations, family and also for the school. As Koizumi (2018:188) stated, it can provide "cultural experiences for the citizens". Certainly, with these attractions. It can promote foreign tourism and also domestic one.

Based on the findings, Kota Tua Jakarta is promoting its city to the wider community. Kota Tua tries to show its local face through various events or festivals which are considered to be capable of introducing the culture of the city. However, it does not mean that all of these activities are local identities of Kota Tua. The city branding of Kota Tua invited some private companies to involve various events or festivals as sponsors. They use this activity as a tool to strengthen their company image as part of their interests.

However, in the branding process in Kota Tua Jakarta, local people and local communities still lack the role even though they are actually involved. Based on the findings, it might be caused by several factors. First, there were still many apathetic people in Kota Tua Jakarta, they did not care about bad luck or good fortune that would occur in Kota Tua Jakarta. Secondly, the socialization carried out by the government to the community was also felt to be not optimal because many people did not know anything about the development of Kota Tua Jakarta. Third, perhaps, the people were not involved in this process, they were given information about developments of Kota Tua Jakarta but their opinions were not responded well by the government or other stakeholders because there were other interests prioritized.

So far, some local people and communities have been involved in the branding efforts of Kota Tua Jakarta. Others were not involved and the rest did not care and seemed apathetic to what happened in Kota Tua Jakarta. For example, there are still many people who do not understand how to care for existing old buildings. They did some damage and did not care that the building was a historical building even though, it is the role of the community and community is extremely important in branding the Kota Tua Jakarta. According to Insch (2011), local communities play an important role in introducing their cities to the wider community because the local community is the source of life that must be involved in determining the long-term economic city, social and direction of the city. The community and the government and stakeholders must articulate a shared vision for the future of the city as a starting 
point for developing city brand strategies in branding efforts (Insch, 2011: 58).

The involvement of local communities and stakeholders is indeed very important for the success of branding Kota Tua Jakarta, but in its implementation, it is felt to be less in accordance with what was planned and expected. Therefore, all elements in the city need to be involved so that the uniqueness of Kota Tua Jakarta is not lost and remains attached. If the government's goal is to maintain Kota Tua Jakarta, then the community must be an important part and have a role in the process of building Kota Tua Jakarta. It is in accordance with the remark of Gelder (2011) saying that the place is set to change the way cities operate to be able to compete, solve problems and innovate more effectively. The involvement of groups, citizens, business people and institutions in doing these efforts must be appreciated because they can handle their city better. For the city branding to succeed, it is important for key stakeholders to join in a partnership. This partnership will jointly develop, create and lead the implementation of brand places, under joint responsibility.

\section{Between City Branding and Imaging}

Many developed cities in the world build their competitiveness by utilizing city branding practices. This is done to pursue broader urban management goals. Cities feel the need to distinguish themselves from each other and assert their individuality in pursuing various economic, political, social and other goals. A city with a strong brand is able to create a variety of positive images to be able to place themselves and win competition with other cities. Therefore, a positive brand identity and image is very important for a city. With branding, cities are able to establish clear identities, strong associations and be different among other cities. Anholt, in his book entitled "Competitive Identity: The New Management brands for Nations, Cities, and Region" (2007: 5) explains that differences are very important for cities to compete with each other. The brand identity of a city is a core concept that explains and expresses the distinctiveness of a city. In addition, according to him, brand image is the most important thing for a city. Brand image is a brand perception that exists in the minds of consumers or society. It is almost the same as the reputation and may not be in accordance with the brand identity. These include the range of associations, memories, hopes and other feelings that are tied to the product, service, or city. This feeling is an important driver of people's behavior. So that brand image is a critical concept for the city.

When we talk about the brand image of a city, what will be in our minds is what characterizes and impresses the city for us. For example, when we talk about the city of Paris, what comes to our mind is about the positive images of this city. Our thoughts are immediately fixed on the beauty of the Eiffel Tower and the romantic atmosphere that is presented. It is different with the case when we talk about Kota Tua Jakarta in Indonesia which is precisely known by its various negative images. Our thoughts will be on the impression of a city that is slum, jammed, flooded, high pollution, high crime rates, and cities that seem haunted. Therefore, from both of these, we can see that Paris has a much stronger brand than Kota Tua Jakarta's. In contrast to the Kota Tua Jakarta, the City of Paris has far more advantages with the identity and positive image that has been formed. Thus, the City of Paris will be far more attractive in the eyes of prospective visitors than with the Kota Tua Jakarta. To form a good image for the city, the city needs to determine the identity of the city first. According to Yananda et.al, identity and image are an inseparable entity. Building the image of the city must begin with building the identity of the city. Finding the identity is the first step in building the image of a city. Identity itself is the foundation that supports image building work. Considering the importance of identity in shaping the image of the city, the identity of the city must be sought, determined, and managed. Every city basically has an identity that is stored in the collective memory of the stakeholder group. In addition, the identity of the city is also stored in physical artifacts 
being the icon of the city (Yananda et al., 2014: 66).

Kota Tua, known as the "to Batavia-an" identity and various Dutch colonial heritage buildings, were in fact unable to sustain its positive image. This is possible because of the unpreparedness of stakeholders in branding and planning a good framework for Kota Tua. The findings indicate that Kota Tua has not fully planned its management of the area. It can be said that Kota Tua superficially has plans and policies but not well realized. Based on the data gathered, this is because of the lack of preparation and management of Kota Tua Jakarta by the provincial government. The provincial government is less interested in cultural and historical aspects. The provincial government is more interested in economic-based matters because it has a circulation of economic circulation that is faster than the circulation of development of cultural heritage building areas.

As previously explained, the practice of city branding is part of urban planning through various efforts to differentiate and strengthen the city's identity in order to be able to compete with other cities. As a result, the implementation is not as easy as imagined. Policy clarity, good cooperation, mature strategic planning, and management that is focused on and integrated in managing the city are needed. According to Vanalo (2017: 54), city branding is widely regarded as a field of study with a focus and policy practice. In expanding the purpose and scope of branding, a concept that implies clear strength is needed, because it relates to urban policies and urban brands. Thus, a brand can play an important role in directing consumer choices. City managers need to look at the image of the city that has been formed.

To make Kota Tua Jakarta a more attractive city, the Provincial Government decided to revitalize and improve city infrastructure. But it takes years in the process. One of the challenges of the Provincial Government is to change the face of a slum, unorganized and haunted city into a clean and beautiful city. On the other hand, sometimes, the effort to form the image of the city is only limited to short-term work. For example, in 2014 when the Provincial Government again wanted to revive Kota Tua Jakarta, the provincial government launched a magnificent plan called "Master Plan for Kota Tua Jakarta". In this plan, the Provincial Government even formed a private consortium and collaborated with other parties to help the process of reviving the region and forming the brand identity of Kota Tua Jakarta. However, in the process, there are often various differences in perceptions between agencies due to high arrogance in each of the relevant agency. Ideally, in carrying out city branding, good partnerships are needed among all stakeholders. This must be taken seriously so that the partnership is effective and does not cause disputes between related agencies. The city brand partnership must cover all the main stakeholders of the city. The main stakeholders are those who can contribute significantly to the future formation of the city through policies, investments, actions, their behavior and communication. Partnerships that are only dominated by one party will not be effective (Gelder, 2011: 39).

The vision and mission of building the image of the Kota Tua must influence the internal (city residents who are part of the city's image) and external part. The vision must also be in line with the programs carried out to actualize them. When the image of Kota Tua is seriously managed, this certainly involves stakeholders and will force them to think strategically, know which competitors will be and know what the advantages and disadvantages of Kota Tua are. So, as a result, the basic image of the city that will be built and developed in Kota Tua Jakarta itself will be known. The image of the city that must be built in this area must be in accordance with the identity of Kota Tua Jakarta itself because the image of the city formed often does not match the identity of the city. This is very important for the purpose of building Kota Tua Jakarta. A goal without a clear and attractive identity is like a boring personality. Kota Tua Jakarta will look unattractive and will not get the attention 
and respect needed or deserved. Identity can make the Kota Tua have a distinctive personality, value and strength that fits the city. In addition, cities and towns also need a brand that is able to sustain identity and shape the image of the city.

According to Baker (2007:26), the purpose of the brand is the totality of perceptions, thoughts, and feelings that customers have about a place. The purpose of brand imaging is an organizing principle that involves the preparation of messages and experiences related to the place to ensure that the product is unique, interesting, memorable, and valuable. The goal of a successful brand is in the hearts of customers, clearly differentiating themselves, giving valuable promises, and simplifying customer choices. The value of a brand is built at every point of contact with customers through an extraordinary experience, not by relying on the physical characteristics of the residence.

\section{Conclusion}

Based on the explanation above, it can be concluded that city branding is used as a tool to position a city stronger. In simple terms, city branding can be defined as the characteristics or identity that you want to show in the form of symbols, slogans, logos, brands, and other attributes attached to the city. However, city branding itself is a matter of building a collective imagination of a city and is a new device in regional development to improve the competitiveness of cities in global competition. At present, Kota Tua Jakarta tries to show its identity globally to attract tourists, investors, talents, and achieve other goals desired by stakeholders. Therefore, city branding is one of the tools for Kota Tua Jakarta to highlight its competitive advantage. Besides, city branding is also used to help Kota Tua Jakarta solve various problems that have been faced. Considering that branding efforts are a process that is not easy and sustainable, doing branding is not an easy matter. Therefore, we need seriousness in building a city that is better than the previous conditions. In its efforts, all groups within the city need to be involved and invited to jointly build Kota Tua Jakarta. It makes it possible to achieve success from branding itself.

The synergy that should be prioritized becomes backward and forgotten in the branding of Kota Tua Jakarta. The fact is that the various efforts being shown by all stakeholders in the city are just a form of imaging needed in building cities. The city needs a positive image to make the city attractive and more visited by visitors. This paper covers how city branding in Kota Tua needs more increasing creative cultural activities with demonstrating significant civic involvement. The city strives to create a strong and positive brand in order to deal with various types of competitive competition with its competitors. The city government and other stakeholders are trying to make the city the main destination for visitors. This will certainly bring economic benefits to the city and of course to stakeholders in the city. Even though in the process, the city needs a unique character and identity "locality" that can be obtained from the community itself. City branding in Kota Tua Jakarta has also shown some changes in a more positive direction. Kota Tua is slowly showing its new face with various forms of positive image that is being carried out. At the end, the authors conclude that city branding is a sophisticated activity that is recognized to increase relevance for planning, development and management of Kota Tua Jakarta.

\section{Acknowledgment}

There is no conflict of interest for this paper. The authors would like to thank all the key actors and stakeholders who are involved for this fieldwork of research and the anonymous reviewer of the journal for their comment on an earlier version. However, all of responsibility this paper on the authors. 


\section{References}

\section{Journal Articles}

1. Bıçakçl, Ayşe Banu. (2012). 'Branding the city through culture: Istanbul, European Capital of Culture 2010', International Journal of Human Sciences, Volume 9, Issue 1, 993-1006.

2. Borer, Michael Ian. (2006). 'The Location of Culture: The Urban Culturalist Perspective', City \& Community, 5:2 June 2006.

3. Briciu,Victor and Briciu, Arabela (2016), 'A Brief History of Brands and The Evolution of Place Branding', Bulletin of the Transilvania University of Brassov Series VII: Social Sciences • Law • Vol. 9 (58) No. 2 2016.

4. Dinardi, Cecilia (2017), 'Cities for Sale: Contesting City Branding and Cultural Policies in Buenos Aires', Urban Studies 2017, Vol. 54(1) 85-101, DOI: $10.1177 / 0042098015604079$

5. Donner,Mechthild.,Horlings, Lummina.,Fatiha,Fort,Vellema, Sietze. (2016), 'Place Branding, Embeddedness and Endogenous Rural Development:Four European Case'.Place Branding and Public Diplomacy, Plagrave Macmillan

6. Fernández, Daniel Barrera and Meethan, Kevin, (2013), 'The Relationship of City Branding and Tourist Promotion: The Case of Plymouth (UK) and Malaga (Spain)', Athens Journal of Tourism, Volume 1, Issue 3, 217-226.

7. Hereźniak, M., Florek, M., Augustyn, A. (2018), ‘On Measuring Place Brand Effectiveness - between Theoretical Developments and Empirical Findings'. Economics and Sociology, 11(2), 36-51. doi:10.14254/2071-789X.2018/11-2/3.

8. Kavaratzis, Mihalis and G. J. Ashworth.(2005), 'City Branding: An Effective Assertion of Identity or a Transitory Marketing Trick?', Jurnal
Tijdschrift voor Economische en Sociale Geografie. Vol. 90, No. 5/2005, 506-514.

9. Kavaratzis,Mihalis and Kalandides, Ares. (2015), 'Rethinking the Place Brand: the Interactive Formation of Place Brands and the Role of Participatory Place Branding', Environment and Planning $A$ 2015, volume 47, 1368 - 1382, doi:10.1177/0308518X15594918

10. Mathewson, David Wallace, (2018), 'Historic Institutionalism and Urban Morphology in Jakarta: Moving Towards Building Flood Resiliency into the Formal Planning and Development System', Journal of Regional and City Planning vol. 29, no. 3, 188-209, December $2018 \quad$ DOI: 10.5614/jrcp.2018.29.3.2

11. Mueller, Andreass and Schade,Michael (2012), 'Symbols and Place Identity:A Semiotic Approach to Internal Place Branding:Case Study Bremen (Germany)', Journal of Place Management and Development, Vol. 5 Issue: $\quad 1,81$ 92, https://doi.org/10.1108/175383312 11209068 .

12. Roubal, Ondřej, (2015), 'Sociology of Branding: "Just Do It" In The "No Limits" World', Communication Today, 2017, Vol. 8, No. 1, 41-51.

13. Soltani,Ali., Pieters,Johannes., Young,Janette \& Sun,Zhaohong (2018), 'Exploring City Branding Strategies and Their Impacts on Local Tourism Success, The Case Study of Kumamoto Prefecture, Japan', Asia Pacific Journal of Tourism Research,23:2,158169, DOI: 10.1080/10941665.2017.141019 5

14. Ye, Lin and Björner, Emma (2018), 'Linking City Branding to Multi-Level Urban Governance in Chinese Mega-Cities: A Case Study of Guangzhou', Cities, volume 80, october 2018, 29-37.

\section{Books}


16. Andersson, Ida (2015) Geographies of Place Branding ; Researching through Small and Medium-Sized Cities, Stockholm,Stockholm University Press.

17. Anholt, Simon. (2007) Competitive Identity, The New Brand Management for Nations, Cities \& Regions, New York,Palgrave Macmillan.

18. Baker, Bill (2007) Destination Branding for Small Cities: The Essential for Succesful Place Branding, Portland, Creative Leap Books.

19. Cabannes, Yves.,Douglass Mike.,and Padawangi,Rita (2018), Cities by and for the people, i Cabannes, Yves.,Douglass Mike.,and Padawangi,Rita (ed), Amsterdam, Amsterdam University Press.

20. Donald, Stephanic Hemelryk and John G. Gammack. (2007) Tourism and the Branded City: Film and Identity on the Pasific Rim, Burlington,Ashgate Publishing Company.

21. Forbes, Dean (2019). Knowledge, creativity and the city, Padawangi, Rita (ed), Routledge Handbook of Urbanization in Southeast Asia, Oxon-New York, Routledge.

22. Gelder, Sicco Van (2011), City Brand Partnership in Keith Dinnie (ed). City Branding: Theory and Cases. Cippenham and Eastbourne, CPI Antony Rowe.

23. Insch, Andrea (2011), Branding the city as an attractive place to live, Keith Dinnie (ed), Cippenham and Eastbourne, CPI Antony Rowe.

24. Kyung, Kim You and Peter Eung-Pyo Kim,(2011), Seoul city branding: the case of seoul's international brand communication,
Keith Dinnie (ed), Cippenham and Eastbourne,CPI Antony Rowe.

25. Koizumi, Motohiro (2018), Connecting with society and people through "Art Projects" in an era of personalization, Cabannes, Yves.,Douglass Mike.,and Padawangi,Rita (ed), Amsterdam,Amsterdam University Press.

26. Lee, Jung-hoon, (2009), Developing distinctive city branding: case of anseong and bucheon south korea, Liping A. Chai (eds), Wagon Lane,Emerald group.

27. Margana, Sri (Eds,). (2010). Kota-Kota di Jawa: Identitas, Gaya Hidup dan Permasalahan Sosial, Yogyakarta, Penerbit Ombak.

28. Nas, Peter J.M, Marlies de Groot and Michelle Schut (2011), Introduction;Variety of Symbols,Nas, Peter J.M (ed), Leiden:Leiden University Press.

29. Government of City of Makasar. (2014). City Branding Makassar. Makasar: Vier Antares Institute.

30. Trott, Sangeeta and Vinod V. Sople. (2016). Brand Equity: An Indian Perspective, New Delhi, PHI Learning Private Limited.

31. Yananda, M.Rahmat, dkk. (2014). Branding Tempat: Membangun Kota, Kabupaten, dan Provinsi Berbasis Identitas, Jakarta, Makna Informasi.

32. Vanalo, Alberto. (2017).City Branding: The Ghostly Politics of Representation in Globlasing Cities, New York, Routledge.

33. Widodo, Johannes, (2019), Historical morphology of coast cities in Southeast Asia, Padawangi, Rita (ed), Routledge.Oxon-New York:Routledge. 